\title{
A Thematic Review of Some Studies Investigating Students' Alternative Conceptions About Energy
}

\author{
Mehmet Altan Kurnaz ${ }^{1, *}$ and Ayşegül Sağlam-Arslan² \\ ${ }^{1} \mathrm{PhD}$ Candidate, Graduate School of Natural and Appl. Sci., Karadeniz Technical University, Trabzon, Turkey \\ ${ }^{2}$ Fatih Faculty of Education, Karadeniz Technical University, Trabzon, Turkey
}

Received 30 November 2010 - Revised 17 February 2011 - Accepted 22 February 2011

\begin{abstract}
Since science education researchers, teachers, curriculum developers, and policy makers elsewhere, who have, or plan to use energy concept in their studies may have a busy schedule to track related studies, a review and synthesis of the studies of alternative conceptions of students about the energy concept are valuable for them. Therefore, the present paper presents a detailed thematic review of students' alternative conception studies about the energy concept to highlight relevant people on the studies' needs, methods, general knowledge claims and implications. Hereby, we may compile and notice where we are on students' alternative conceptions related with energy concept. To this end, each study was described by using a thematic matrix. The aim of alternative conception studies about energy concept generally have been to emerge students' understanding, determine appropriate age to teach energy concept, and compare understanding based on age or culture. While the methods of studies on exploring students' understanding consist of interviews, paper and pencil surveys, and free writing, their analysis consist of classification, comparison, statistical, description, interpretation and praxeological. In light of the general knowledge claims, it can be deduced that most of the studies has highlighted that students have alternative conceptions about energy concept. The studies under investigation generally recommended taking into account their findings in teaching processes.
\end{abstract}

Keywords: Thematic Review, Energy Concept, Alternative Conceptions, Science Education, Physics Education

\section{Introduction}

Constructivist learning approach suggests that learning happens when new knowledge is connected to existing knowledge (Bodner, 1990; Yager, 1991; Mathews 2000; Dysthe, 2002; Taber, 2002). According to this learning approach, students may generalize new knowledge by filtering it through experience, mental structure, abilities and beliefs. Therefore, students structure their perceptions in accordance with their existing knowledge (Osborne \& Wittrock, 1983; Nakhleh, 1992; Osborne \& Freyberg, 1996). However, if students' prior knowledge does not correspond to scientific definitions, students may fail to learn meaningfully (Bodner, 1990; Çalık, 2006; Özsevgeç, 2006). In other words, students can not improve their perceptions scientifically unless their teachers, i.e. science educators do not have a deep understanding of the concepts they will teach (Carey, 1986). As noted before, since alternative conceptions of students are used as a starting point for advanced learning, recent studies have concentrated on students' alternative ideas (Kurnaz \& Çalık, 2008).

\footnotetext{
*Correspondence Author: Phone: +90-462-377-7165 Fax:+90-462-248-7344 E-mail: altan.kurnaz@gmail.com
} 
When we look at relevant literature, we encounter with a large number of studies regarding students' alternative ideas on concepts such as force, motion, heat, temperature, power, and energy. Among these concepts, energy concept seems to come to the fore due to its abstract, complex, social and interdisciplinary nature (Kurnaz, 2007; Sağlam Arslan \& Kurnaz, 2009; Kurnaz \& Sağlam Arslan, 2009). Numerous studies were conducted on this issue in order to reveal students' existing perceptions of energy concept (e.g. Watts, 1983; Duit, 1984; Driver \& Warrington, 1985; Finegold \& Trumper, 1989; Trumper, 1993, 1996, 1997a, 1997b, 1998; Trumper \& Gorsky, 1993; Goldring \& Osborne, 1994; Odell, 1997; Konuk \& Kılıç, 1999; Papadouris et al., 2004; Küçük et al., 2005; Köse et al., 2006; Ünal Çoban, et al., 2007; Hirça et al., 2008; Yuenyong et al., 2008; Boylan, 2008). As a result of these studies, different findings and results were obtained regarding the alternative conceptions of students. The review of these studies by interrelating them will make a contribution to our existing body of knowledge. Moreover, teachers and/or researchers have difficulty in accessing all these studies together. Therefore, when we take these facts into account, we believe our study on presenting the review of previous related studies to the concerning audience will be effective. For this reason, a thematic review should be undertaken by means of a matrix with needs, research methodologies (sample, data collection and data analysis), general knowledge claims (findings and results) and implications on students' alternative conceptions.

The aim of this study is to investigate alternative ideas reported in the literature about energy concept and raise awareness in this sense. In this context, the following questions were asked:

1. What are the needs of the studies?

2. What are the reseach methods (sample, data collection and data analysis) of the studies?

3. What are the major findings of the studies?

4. What are the major results of the studies?

5. What kinds of implications have been suggested in the studies?

\section{Significance}

The analysis of studies about energy concept on which many researchers focused may enable revealing the core of these studies and outlining the development process of the concept starting from first studies up to now. Therefore, this study will both present the researchers a synthetic perspective and help in implementation of effective researches. On the other hand, the synthesis of related literature will facilitate access to knowledge about this concept that draws the attention of teachers, curriculum developers, and policy makers due to its interdisciplinary nature.

Only one study about energy has been conducted within this perspective (Kurnaz \& Çalık, 2009). In fact, the study of Kurnaz \& Çalık (2009) is about studies on teaching energy, not alternative conceptions of students. In other words, there is no science education study which investigates thematically the alternative conceptions of students about energy concept. In this manner, this thematic review fills in this gap. It is also believed that this thematic review is one of the best way to highlight science education researchers, teachers, curriculum developers, and policy makers on the related studies' needs, methods, general knowledge claims and implications. Hereby, science education researchers, teachers, curriculum developers, and policy makers will be able to easily adapt general knowledge claims and implications of the studies to their own practices. On the other hand, researchers will also easily adapt the needs and methods of the studies to their future studies, and they will become 
conscious about the trends of the studies on the alternative conceptions of students. Hereof, researchers may focus on unexplored research areas for further studies.

\section{Limitation of the study}

As a result of investigating databases such as ERIC, Springer, and EBSCOHOST the researchers reached 132 studies related to energy concept. As a result of the first classification, these studies were found to concentrate on the subjects of teaching energy, students' misconceptions of energy and related concepts, learning energy, energy's conceptual framework. Therefore, this paper is restricted only with the 25 research studies that are about 'student understandings of energy and related concepts' in the last three decades.

\section{Methodology}

Within the framework of the research questions posed to examine the perceptions of students regarding energy and related concepts; the matrix used by Çalık, Ayas \& Ebenezer (2005), Ünal, Çalık, Ayas \& Coll (2006), and Kurnaz \& Çalık (2009) was adapted to our study. All studies were analyzed using this matrix which consists of four basic elements, i.e. needs, research methods -sample, data collection and data analysis-, findings, results and implications for teaching and learning. Thus, general trends, differences and common points were revealed. The studies examined with the method described above were presented using thematic matrices.

\section{Needs of the Studies}

When related studies were examined, it was found that most of them were carried out with the purpose of disclosing students' alternative conceptions although they focused on different points. A study (Trumper, 1993) was conducted with a need to investigate the appropriate age level for teaching of energy; another study (Trumper \& Gorsky, 1993) was conducted showing a need to investigate the effect of cognitive and personal factors on perceptions and another study for a need to investigate the effects of cultural factors on learning.

Watts (1983) suggests that energy is related to many subjects in curricula and adds that students are introduced with energy concept long before formal education. In this study, the researcher calls the gains of the students prior to formal education as alternative conceptions and indicates to the need for investigating what these gains are. Duit (1984) claims that physics classes are expected introduce physical energy concept, but there are some problems at this point (in introducing energy). Therefore, he claims that regarding the introduction of energy concept; firstly the perspective which facilitates understanding should be analyzed and students' and in this sense the types of perceptions developed by students should be examined. Similarly, Papadouris et al. (2004) highlight the need to question the effects of defining energy concept as 'a model that accounts for changes in certain physical systems' on student perceptions. Driver \& Warrington (1985) suggest that students might be taught scientific perspectives by taking their perceptions into account, modifying these perceptions and increasing their quality. The researchers also discuss that there are some studies in the literature in this sense, but few of them are argued to investigate how students make use of the conservation of energy in problem solving. Finegold \& Trumper (1989) aimed to develop an instructional approach so as to bridge the gap between the prior knowledge of students about energy concept and scientific views. Furthermore, they stated that they felt the need to investigate students' alternative conceptions to lay the foundations of this aim. 
Trumper (1996) states that secondary students have alternative conceptions about energy concept and those prospective teachers should be inquired about whether they got proper perceptions about this concept. Similarly, Trumper (1997b) also suggests that the perceptions of elementary teachers should be investigated either, because they will teach energy concept. In another study, Trumper (1997a) suggests that Israeli biology teachers teach physics at schools and use energy concept in biology lessons, therefore their perceptions about energy should also be investigated. With a similar reasoning, Trumper (1998) suggested that prospective physics teachers should be investigated about whether they could develop a scientific perception about energy concept as a result of their university study. It's suggested by Konuk \& Kılıç (1999) that the perceptions of prospective teachers about the energy sources of plants and animals, and by Köse et al. (2006) that their misconceptions about energy and energy sources should be investigated in order to determine their proficiencies. Odell (1997) suggests that the students who attended to introductory level science course should be inquired about whether they learnt about the conservation of energy and mass and whether the gains of students showed differences based on students' subject fields. Kurnaz (2007), Kurnaz \& Sağlam Arslan (2009), and Sağlam Arslan (2009) emphasized that there may be reasons for students' misconceptions other than their learning difficulties. Researchers highlight the fact that the way knowledge is presented to students may lead to misconceptions and/or alternative conceptions and they justified their studies by pointing out to the need to explore this relationship. Moreover, Sağlam Arslan \& Kurnaz (2009) showed that there are scant studies on the views of students about energy and related concepts at university level.

Trumper (1993) cited in his study that, many studies determined that students developed scientifically incorrect perceptions regarding physics concepts before formal education. Trumper states that the most usually encountered concept among these is energy and in order to prevent scientifically incorrect perceptions regarding energy, it should be questioned at which age to start its instruction.

Trumper \& Gorsky (1993) state that some studies investigated students' alternative conceptions and others focused on how to remedy them. However, the researchers state that few studies explored cognitive and personal factors in the perception of a new concept and their effects on the development of alternative concepts should be investigated.

Goldring \& Osborne (1994) highlighted that the basic perceptions of students regarding energy and related concepts and their abilities in explaining these with quantitative and qualitative variables should be explored. Hırça et al. (2008) state that although there are ample studies on energy concept, few of these investigated students' transfer of theoretical knowledge into novel situations and their perceptions of energy.

Küçük et al. (2005) suggest that it should be investigated how the Turkish students perceived energy and related concepts and a ground for the solution of common problems should be established. Yuenyong et al. (2008) state that learning is not only constructing knowledge but also expressing a standpoint with this knowledge embedded in one's own culture. In other words, learning has a socio-cultural nature and contextual bases should be taken into account. In this sense, the comparison of the perceptions of students from different countries and cultures (e.g. Thailand and New Zealand) is suggested to contribute to science teaching and learning.

Ünal Çoban et al. (2007) emphasized the need for examining whether the students perceived energy concept as expected after elementary education process. Boylan (2008) stated that energy and climate change concepts became more important in the society due to environmental changes and students' perceptions on these issues should be revealed. Yürümezoğlu et al. (2009) stated that as a result of the revised science and technology 
curriculum, students' perceptions about how energy and related concepts, the source, form and transfer of energy should be investigated.

\section{Methodologies of the studies}

The analyses regarding the methodologies used in the studies conducted to determine how energy concept was perceived by students are presented in Table 1. As can be seen in Table 1, five types of methodologies were used in the studies carried out to determine how students perceived energy concept: survey $(n=5)$, cross-age comparison $(n=5)$, case study $(n=4)$, cross-cultural comparison $(n=1)$, experimental $(n=1)$ and longitudinal study $(n=1)$. In 8 studies, it was found that the methodology was not stated.

Out of the studies, 10 (Trumper, 1996, 1997a, 1997b, 1998; Odell, 1997; Konuk \& Kilıç, 1999; Köse et al., 2006; Kurnaz, 2007; Kurnaz \& Sağlam Arslan, 2009; Sağlam Arslan \& Kurnaz, 2009) were conducted with university students, 9 (Watts, 1983; Trumper, 1993; Goldring \& Osborne, 1994; Papadouris et al., 2004; Küçük et al., 2005; Ünal Çoban, et al., 2007; Hırça et al., 2008; Boylan, 2008; Yürümezoğlu et al., 2009) with elementary students and 5 (Duit, 1984; Driver \& Warrington, 1985; Finegold \& Trumper, 1989; Trumper \& Gorsky, 1993; Yuenyong et al., 2008) were conducted with secondary students. In a study (Sağlam Arslan, 2009), secondary, undergraduate and graduate students participated together.

In most of the studies, sampling criteria was not mentioned. Ünal Çoban et al. (2007) preferred stratified sampling, Kurnaz (2007) preferred purposive sampling and Küçük et al. (2005) preferred random sampling methods. Moreover, Odell (1997) built his sample from volunteers.

Table 1. The methodologies of the studies examining the perceptions of students regarding energy concept

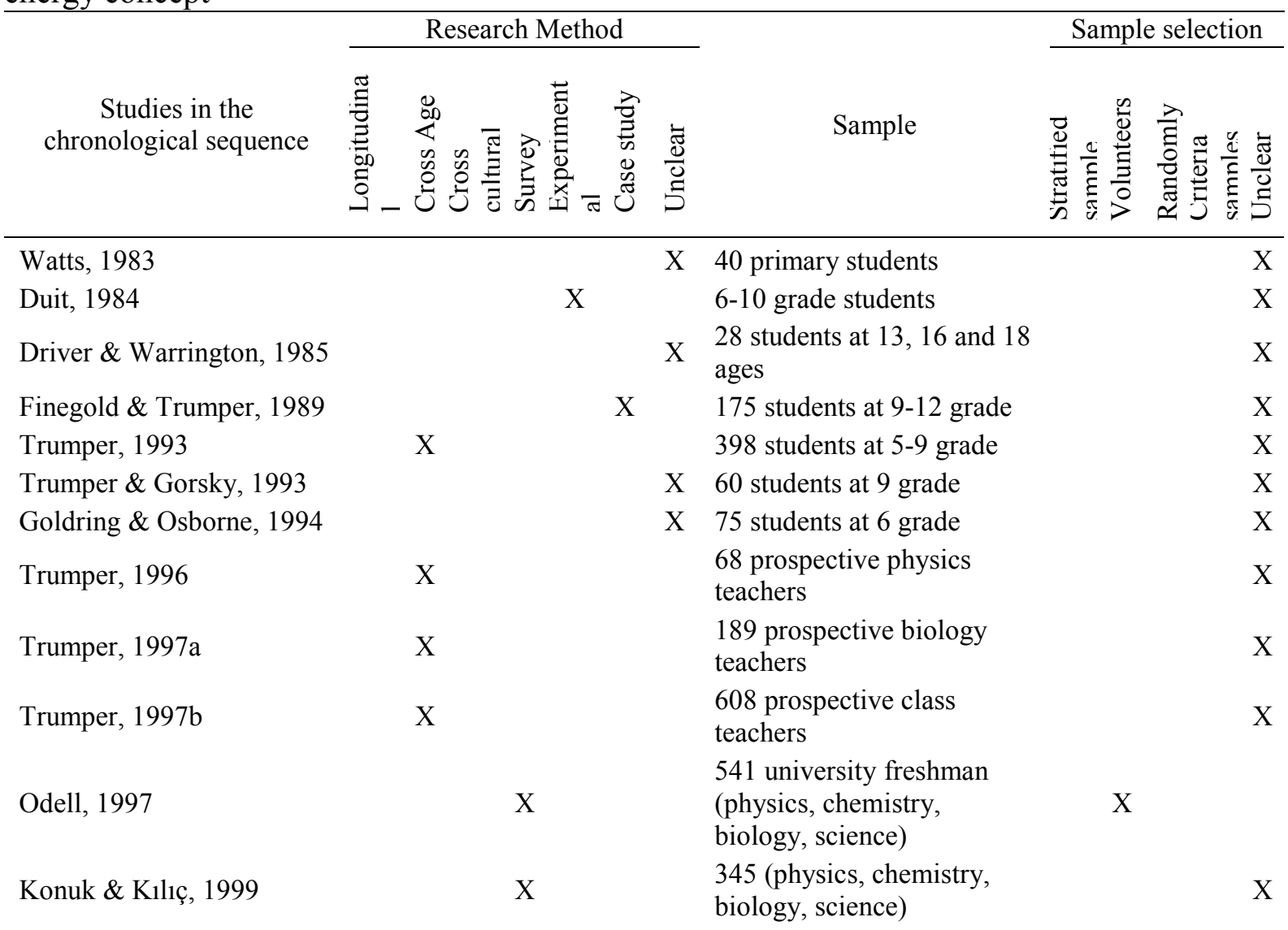


Trumper, $1998 \quad \mathrm{X}$

Papadouris vd., 2004

Küçük et al., 2005

Köse et al., 2006

Ünal Çoban et al., 2007

Kurnaz, 2007

Yuenyong et al., 2008

Boylan, 2008

Hirça et al., 2008

Kurnaz \& Sağlam Arslan, 2009

Sağlam Arslan \& Kurnaz, 2009

Yürümezoğlu et al., 2009

Sağlam Arslan, 2009

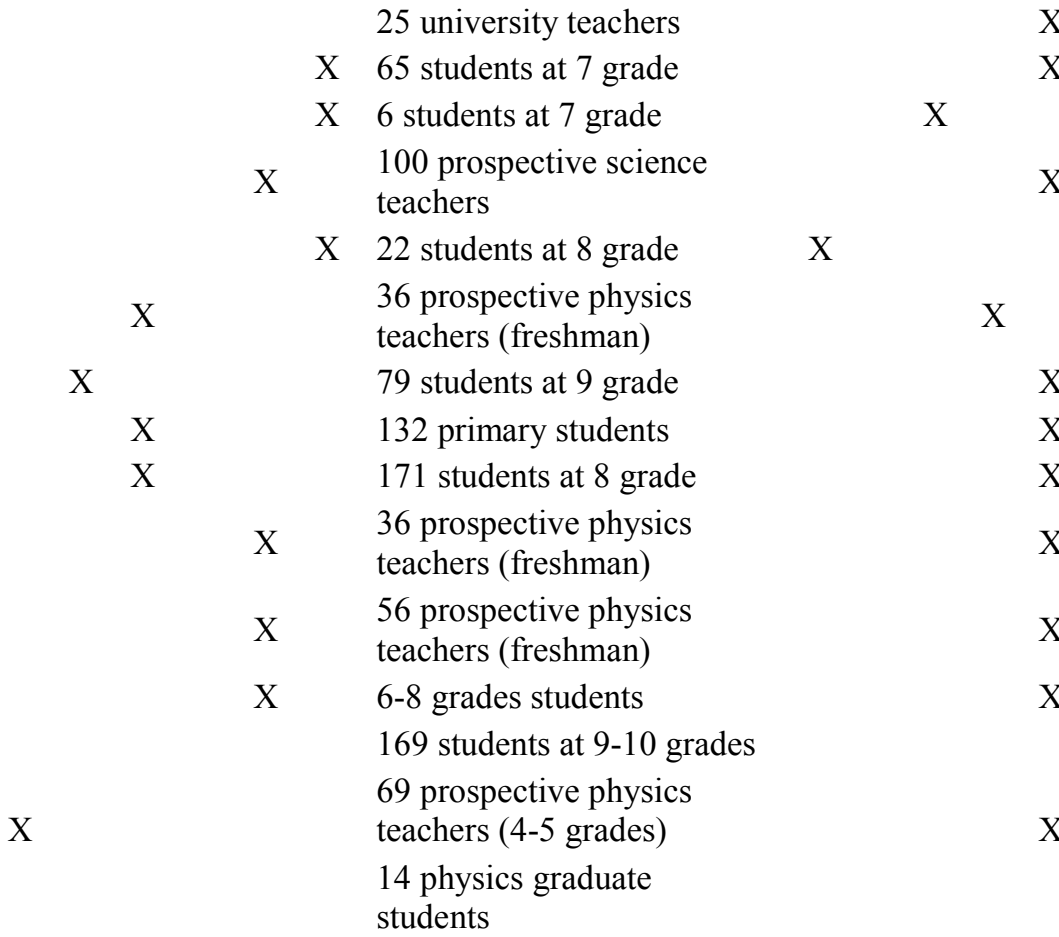

prospective teachers

$\mathrm{X}$

$\mathrm{X}$

$\mathrm{X}$

$\mathrm{X}$

$\mathrm{X}$

$\mathrm{X}$

$\mathrm{X}$

$\mathrm{X}$

$\mathrm{X}$

\section{Data Collection Techniques and Analysis Methods}

The data collection techniques and methods of analysis used in the studies conducted to determine how energy concept was perceived by the students are presented in Table 2.

Table 2. Data collection and analysis methods of the studies investigating students' perceptions

\begin{tabular}{|c|c|c|c|c|c|c|c|c|c|c|c|}
\hline \multirow{2}{*}{$\begin{array}{c}\text { Studies in the } \\
\text { chronological sequence }\end{array}$} & \multicolumn{4}{|c|}{ Data Collecting Methods } & \multicolumn{7}{|c|}{ Analysis Methods } \\
\hline & I & OEQ & MCQ & FW & $\mathrm{C}$ & $\mathrm{CN}$ & SA & DI & DA & $\mathrm{P}$ & $\mathrm{U}$ \\
\hline Watts, 1983 & $\mathrm{X}$ & & & & & & & & & & $\mathrm{X}$ \\
\hline Duit, 1984 & & & $\mathrm{X}$ & & & & & & & & $\mathrm{X}$ \\
\hline $\begin{array}{l}\text { Driver \& Warrington, } \\
1985\end{array}$ & $\mathrm{X}$ & & & & $\mathrm{X}$ & & & & & & \\
\hline Finegold \& Trumper, 1989 & $\mathrm{X}$ & & & $\mathrm{X}$ & $\mathrm{X}$ & & & & & & \\
\hline Trumper, 1993 & $\mathrm{X}$ & $\mathrm{X}$ & & $\mathrm{X}$ & $\mathrm{X}$ & & & & & & \\
\hline Trumper \& Gorsky, 1993 & $\mathrm{X}$ & $\mathrm{X}$ & & $\mathrm{X}$ & & & $\mathrm{X}$ & & & & \\
\hline Goldring \& Osborne, 1994 & $\mathrm{X}$ & $\mathrm{X}$ & $\mathrm{X}$ & $\mathrm{X}$ & $\mathrm{X}$ & & & & & & \\
\hline Trumper, 1996 & $\mathrm{X}$ & $\mathrm{X}$ & & $\mathrm{X}$ & $\mathrm{X}$ & & & & & & \\
\hline Trumper, 1997a & $\mathrm{X}$ & $\mathrm{X}$ & & $\mathrm{X}$ & $\mathrm{X}$ & & & & & & \\
\hline Trumper, 1997b & $\mathrm{X}$ & $\mathrm{X}$ & & $\mathrm{X}$ & $\mathrm{X}$ & & & & & & \\
\hline Odell, 1997 & & $\mathrm{X}$ & $\mathrm{X}$ & & & $\mathrm{X}$ & $\mathrm{X}$ & & & & \\
\hline Konuk \& K1lıç, 1999 & & $\mathrm{X}$ & & & & & $\mathrm{X}$ & & & & \\
\hline Trumper, 1998 & $\mathrm{X}$ & $\mathrm{X}$ & & & $\mathrm{X}$ & & & & & & \\
\hline Papadouris et al., 2004 & & & $\mathrm{X}$ & & $X$ & & & & & & \\
\hline Küçük et al., 2005 & $\mathrm{X}$ & & & & & & & & & & $\mathrm{X}$ \\
\hline Köse et al., 2006 & $\mathrm{X}$ & $\mathrm{X}$ & $\mathrm{X}$ & & $X$ & & $\mathrm{X}$ & & & & \\
\hline Ünal Çoban et al., 2007 & $\mathrm{X}$ & & & & $X$ & & & & & & \\
\hline Kurnaz, 2007 & & & $\mathrm{X}$ & & & & & $\mathrm{X}$ & & $\mathrm{X}$ & \\
\hline Hirça et al., 2008 & & $\mathrm{X}$ & & & & & $\mathrm{X}$ & & & & \\
\hline
\end{tabular}


Yuenyong et al., 2008

Boylan, 2008

Kurnaz \& Sağlam Arslan, 2009

Sağlam Arslan \& Kurnaz,

2009

Yürümezoğlu et al., 2009

Sağlam Arslan, 2009

I: Interviews ( $\mathrm{n}=13)$; OEQ: Open

ended questions ( $\mathrm{n}=10)$; MCQ:

Multiple choice questions ( $\mathrm{n}=13)$;

FW: Free writing $(\mathrm{n}=7)$
$\mathrm{X}-\mathrm{X}$

$\mathrm{X}-\mathrm{X}$

$\mathrm{X} \quad \mathrm{X} \quad \mathrm{X} \quad \mathrm{X}$

$\mathrm{X} \quad \mathrm{X} \quad \mathrm{X}$

$\begin{array}{llll}X & X & X & X\end{array}$
C: Classification ( $\mathrm{n}=14)$; $\mathrm{CN}$ : Comparison $(\mathrm{n}=3)$; SA: Statistical

Analysis ( $\mathrm{n}=7)$; DI: Descriptive-interpretative analysis $(\mathrm{n}=2)$; DA:

Descriptive analysis $(\mathrm{n}=1)$; P: Praxeological analysis $(\mathrm{n}=2)$; $\mathrm{U}$ :

Unclear $(n=3)$

\section{Data Collection Methods}

Triangulation of data in researches increases the reliability and validity (Cohen \& Manion, 2007) therefore mixed methods are usually preferred (Guba \& Lincoln, 1989; Harrison \& Treagust, 2000). When Table 2 is examined, it can be seen that researchers collected data using interviews, multiple choice and open ended questions, and free writing methods. Among the studies, 10 were found to include multiple methods of data collection. The most frequently used methods of data collection were multiple choice questions and interviews.

When Table 1 and 2 are examined in terms of preferred research methods and data collection techniques, it can be seen that researchers prefer data collection tools in accordance with their research methods (Table 3).

Table 3. The comparison of data collection tools with research methods

\begin{tabular}{lccccc}
\hline Research Approach & Number & I & MCQ & OEQ & FW \\
\hline longitudinal & 1 & 1 & 1 & - & - \\
cross-age comparison & 4 & 4 & 4 & 1 & 4 \\
cross-cultural comparison & 1 & - & 1 & - & - \\
survey & 5 & - & 4 & 2 & - \\
experimental & 1 & - & - & 1 & - \\
cross-age & 4 & 2 & 1 & 3 & 1 \\
unclear & 7 & 6 & 2 & 3 & 2 \\
\hline
\end{tabular}

According to Table 3, the researchers who used survey method were found to collect data using multiple-choice and open-ended questions, those who used cross-age design were found to collect data using interviews and multiple choice questions, and eventually those who used case study method were found to focus on collecting data making use of all kinds of tools.

\section{Multiple Choice Questions}

Of the researchers who used multiple choice questions, Finegold \& Trumper (1989), Trumper \& Gorsky (1993) and Trumper (1993) asked students to choose one of the five different definitions of energy concepts. Trumper $(1996 ; 1997 \mathrm{a} ; 1997 \mathrm{~b} ; 1998)$ directed 42 questions to students involving choices as "true, false, don't understand, not sure" regarding 
the real situations in the studies they carried out in different years. Hirça et al. (2008) asked their student 20 questions involving 4-choice, 1 true answer questions, Odell (1997) asked students 20 5-choice, 1 correct answer questions as pre-test and post-test (total 40 questions). Goldring \& Osborne (1994) asked students multiple choice questions regarding power and energy concepts, whereas Konuk \& Kılıç (1999) asked multiple choice questions regarding the source of energy. Köse et al. (2006) asked total 14 five-point likert type multiple-choice questions regarding the energy sources of plants and animals. Boylan (2008) asked students total 8 questions, 2 of which using four-choice and three-choice questions and 6 of them truefalse questions. Yuenyong et al. (2008) asked students questions presenting choices that would elicit the reasons for their agreement or disagreement (Figure 1). However, researchers addressed some specific questions based on countries because the sample included students from New Zealand and Thailand. An example question used by the researchers was provided below.

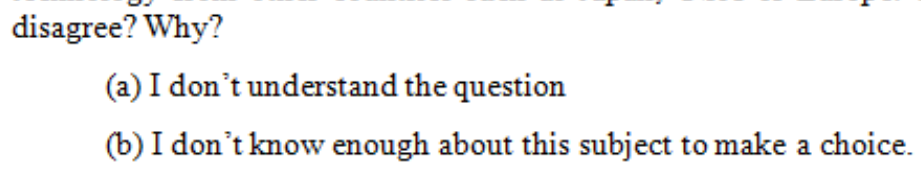
disagree? Why?

(a) I don't understand the question

(b) I don't know enough about this subject to make a choice. technology from other countries such as Japan, USA or Europe. This is useful for our country. Do you agree or I agree:

(c) Because we must spend large amounts of money but there is sometimes nothing that is useful in society.(d) For Thai students: Because greater amounts of money should be spent on foundation education, industrial research or community industrial research (One Tumbol One Product).

For New Zealand students: Because greater amounts of money should be spent on foundation education , industrial research or community industrial research

(e) Because it is more cost effective. Thailand (or New Zealand) does not spend on any budget for research bur we could still use technology that is imported from developed countries.

I disagree:

(f) Because investment for studying research will develop Thai (or New Zealand) scientists' quality even though sometimes research will fail.

(g) Because Thailand (or New Zealand) must import high cost technology and this upsets the balance of imports and exports.

(h) Because we should develop energy technology stemming from our own requirements and solve our local problems.

(i) None of these choices fits my basic viewpoint. My view is

Figure 1. Example: a multiple-choice question used by Yuenyong et al.

Multiple choice questions concentrate on what students remember rather than what they perceive (Kurnaz \& Çalık, 2009), therefore, by using this type of questions, the researchers seem to focus on revealing what students remembered regarding energy concept rather then what they perceived. For this reason, as can be seen in Table 2, the researchers who collected data using multiple choice questions were also found to collect data using interviews, open ended questions or free writing.

\section{Interviews}

This tool is effective in observing and investigating students' views on a sample case or event and revealing alternative conceptions (White \& Gunstone, 1992). Watts (1983), 
Finegold \& Trumper (1989), Trumper (1993; 1996; 1997a; 1997b; 1998), Trumper \& Gorsky (1993), and Papadouris et al., (2004) conducted interviews based on pictures of real situations (Figure 2).
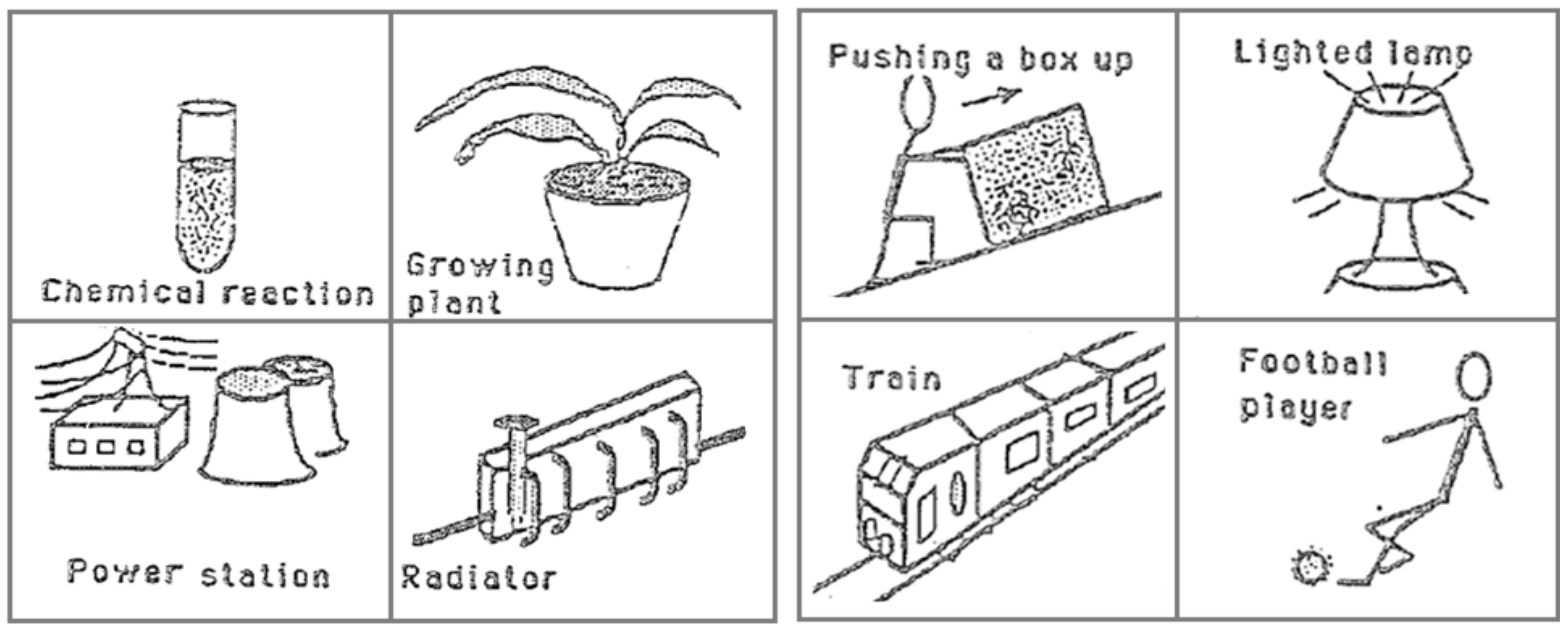

Figure 2. Examples of real situations used in the studies of Finegold \& Trumper (1989).

In the interview with case study approach developed by Osborne \& Gilbert (1980), students were asked to give examples related and unrelated to the concept and give explanations based on the pictures provided (Watts, 1983; Finegold \& Trumper, 1989). Driver \& Warrington (1985) asked their students to interpret the incoming/outgoing energy values for a system based on the functions of pulley system, lever, inclined surface and water tribune. Küçük et al. (2005), and Ünal Çoban et al. (2007) made use of interviews to determine the perceptions of students regarding energy and related concepts; whereas Goldring \& Osborne (1994), and Köse et al. (2006) attempted to use interviews to support the data from other data collection tools.

\section{Open Ended Questions}

Goldring \& Osborne (1994) asked students two types of open ended questions: (I) questions seeking the difference of scientific and daily uses of energy concept, for example, "People say that energy is used up-for example when they talk about a world 'energy crisis'. When might it make sense to say that energy is used up?"(p.27), (II) questions seeking for the perceptions about heating, work, energy and power, for example, "A pot full of water was put on the cooker, and the ring turn on. Was energy being supplied to the water? Was work being done? Explain your reason?" (p. 27). Odell (1997) asked students using 6 open ended questions, what energy, the conservation of energy and open/closed systems were. Duit (1984) wanted students to write the definitions of work, power, force and energy concepts, give examples and to explain the weight concept lifted by the electric motor wired to the battery when the switch is closed as shown in Figure 3. 


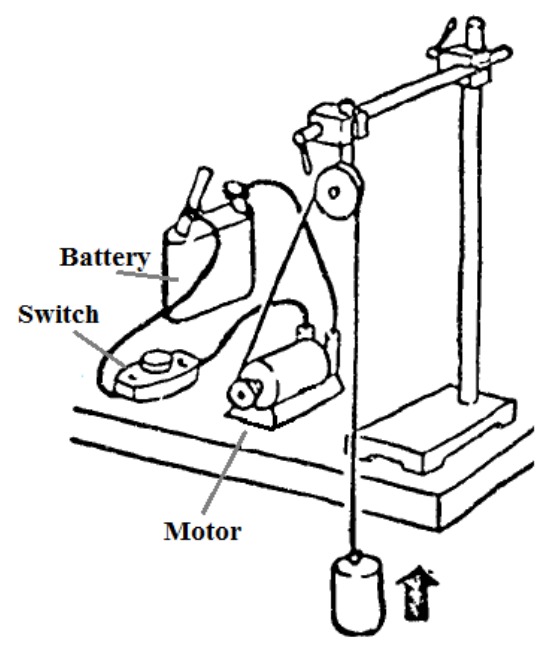

Figure 3. The picture used by Duit during data collection (p. 61)

Köse et al. (2006) asked teacher candidates open ended questions to determine the matters that don't give energy, explain their answers and express their views about energy. Kurnaz (2007) asked 8 open ended questions which requires the students to do calculation, explanation, interpretation, definition and classification; whereas Kurnaz \& Sağlam Arslan (2009) asked 5 open ended questions. One of the questions used by Kurnaz \& Sağlam Arslan (2009) is as follows:

Question 3. What is the distance to be taken into account when calculation the potential energy in a system made up of the earth and a meteor falling on it? (The distance between the meteor and the earth's surface / the distance between the meteor and the earth's center) Explain (p.78).

Sağlam Arslan \& Kurnaz (2009) asked 5 questions, all addressing energy, power and force concepts. One of the questions used by the researchers is as follows:

Question 5. Can energy be property of an object? Why?

Can power be property of an object? Why?

Can force be property of an object? Why? (p. 6).

Papadouris et al. (2004) made use of the pictures of real cases shown in Figure 4. Researchers, without talking with the students about energy, wanted the students to give explanations of how the rotation shown in the picture can happen.

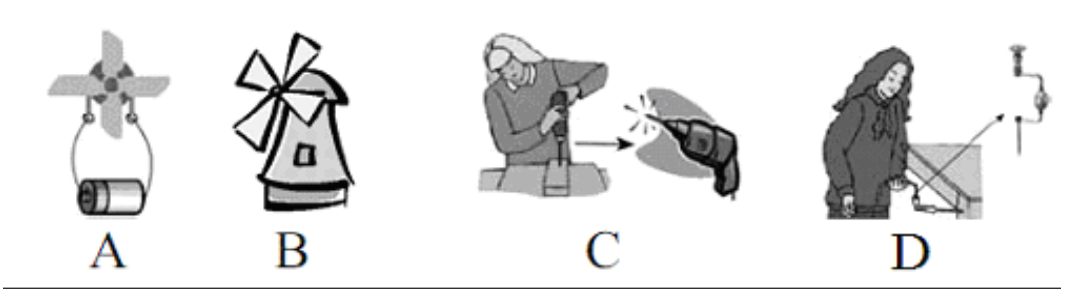

Figure 4. The task of modeling energy in order to determine the reason of change 
Yürümezoğlu et al. (2009) posed open ended questions to students about energy concept, energy source, energy form and energy transfer. They made use of pictures related to daily life as shown in Figure 5.

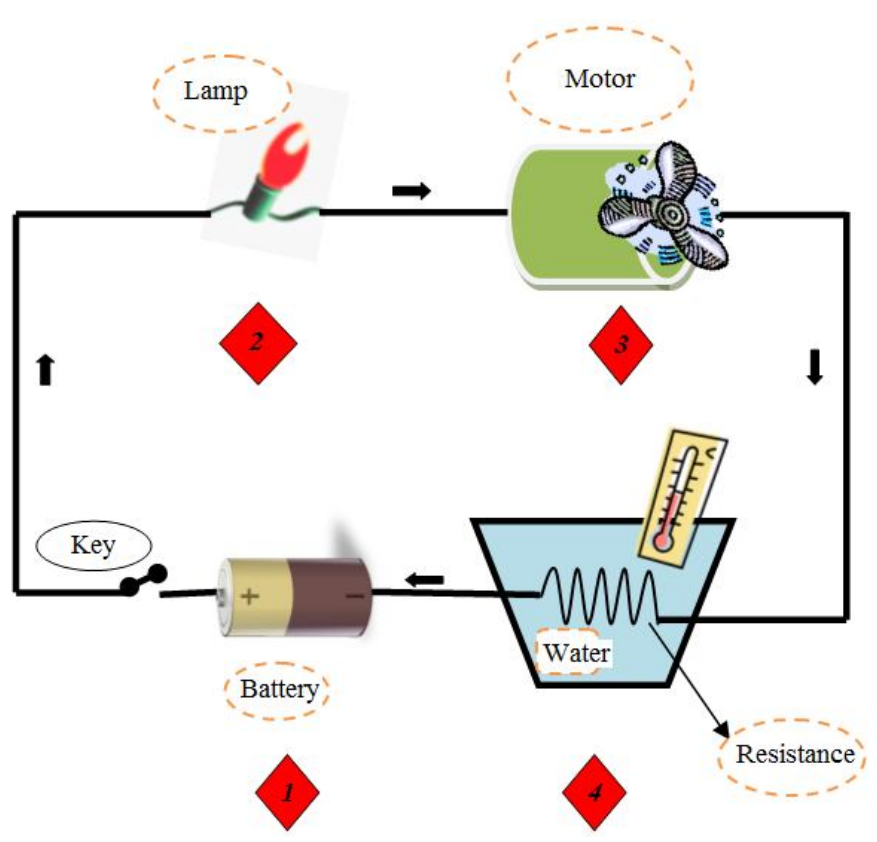

Figure 5. Determination of energy transformation in the numbered places

Sağlam Arslan (2009) collected data by using a 2-step method. At the first step, she collected data to determine the abilities of students to define energy concept. At the second step, she collected data about the abilities of students to represent energy concept graphically. The questions in the second category require students to draw graphics by using the formulas of potential and kinetic energy as shown in the example below.

Problem: In a frictionless environment, an object with mass $\mathrm{m}$ is thrown vertically upwards with initial velocity V0. Please respond to the following questions by considering the upward motion of this object before it reaches the maximum point.

a) Draw the graphs of potential energy (EP) versus height, kinetic energy (EK) versus height, and total (ET) energy versus height by referring to the equation. $E_{p}=m \cdot g \cdot h$

b) Draw the graphs of kinetic energy (EK) versus velocity, potential energy (EP) versus velocity, and total (ET) energy versus velocity by referring to the equation. $E_{K}=1 / 2 m V^{2}$
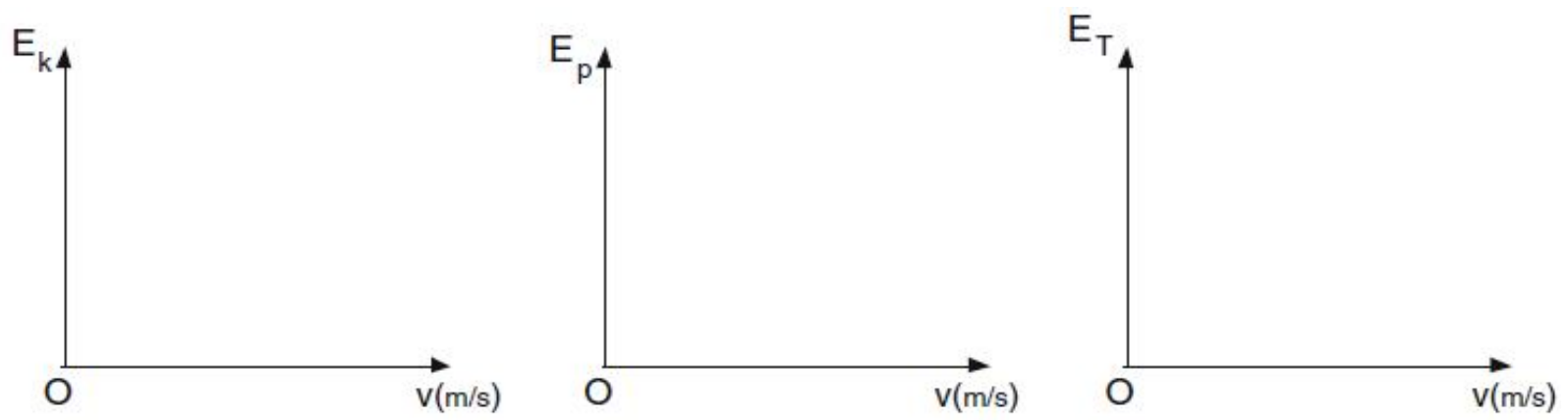


\section{Free Writing}

As shown in Table 3, in 7 studies free writing was used as a data collection method. Finegold \& Trumper (1989), Trumper (1993; 1996; 1997a; 1997b), and Trumper \& Gorsky (1993) wanted the students to write three things about energy concept and give examples about their explanations. Goldring \& Osborne (1994) wanted students to make statements about basic concepts such as "power and energy", "energy and energy sources", "work and energy". As shown in Figure 6, Trumper (1996; 1997a; 1997b) asked students to make predictions and give explanations about the energy of an object moving on an inclined surface in some of his studies.

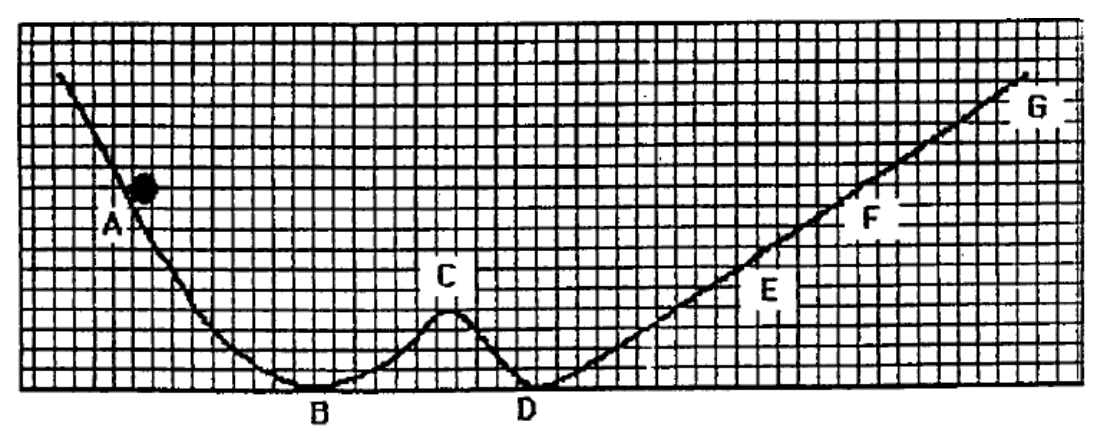

Figure 6. Object moving on an inclined surface (p. 183, Trumper, 1996)

\section{Analysis Methods}

When Table 1 and 2 are examined in terms of preferred research methods and data collection techniques, the data collection tools preferred by researchers in accordance with research methods can be seen (Table 4).

Table 4. The comparison of research methods and analysis approaches

\begin{tabular}{|c|c|c|c|c|c|c|c|c|}
\hline Research Approach & Number & $\mathbf{C}$ & $\mathbf{C N}$ & SA & DI & DA & $\mathbf{P}$ & $\mathbf{U}$ \\
\hline longitudinal & 1 & 1 & & & & & & \\
\hline cross-age comparison & 4 & 5 & & & & & & \\
\hline $\begin{array}{l}\text { cross-cultural } \\
\text { comparison }\end{array}$ & 1 & & & 1 & & & & \\
\hline survey & 5 & & 1 & 4 & 1 & & 1 & \\
\hline experimental & 1 & & & & & & & 1 \\
\hline cross-age & 4 & 3 & 1 & 1 & 1 & 1 & & \\
\hline unclear & 8 & 5 & 1 & 1 & 1 & & 1 & 2 \\
\hline Total & 23 & 14 & 3 & 7 & 3 & 1 & 2 & 3 \\
\hline
\end{tabular}

It can be seen in Table 4 that most of the researchers preferred classification method. Classification method was mostly used in cross-age studies. In the studies conducted with survey method, data were usually tested statistically.

As can be seen in Tables 3 and 4, descriptive analysis is the least preferred method. Sağlam Arslan \& Kurnaz (2009) used descriptive analysis to reveal students' perceptions. Kurnaz (2007), and Kurnaz \& Sağlam Arslan (2009) used descriptive and interpretive 
analyses in their study as well as praxeological analysis. By using praxeological analysis approach, researchers revealed solution strategies (techniques) for the problems they presented to the students and based on the explanations (technologies) that justify these strategies, they revealed individual understandings of the students regarding energy. Furthermore, Kurnaz (2007), and Kurnaz \& Sağlam Arslan (2009) compared individual and institutional understandings of the students regarding energy concept and examined the differences. Yuenyong et al. (2008) compared the perceptions of students from New Zealand and Thailand regarding energy and related subjects using Z-scores. Researchers carried out the necessary calculations using the following formula:

$$
Z_{\sigma}=Z_{\alpha} / 2 \sqrt{\frac{P_{1}\left(1-P_{1}\right)}{n_{1}}+\frac{P_{2}\left(1-P_{2}\right)}{n_{2}}} *
$$

Trumper \& Gorsky (1993) evaluated the participants in two groups as successful and unsuccessful in order to determine their achievement in learning energy concept and the relationship between cognitive and personal factors. In this process, the researchers used ttest. Likewise, Konuk \& Kılıç (1999) also used t-test at $p<0.05$ significance level. Odell (1997) is another researcher who used t-test in order to examine differences between the perceptions of students from different disciplines. For this aim, Odell (1997) used tests before and after education process in order to determine the development of students' perceptions. Odell (1997) calculated the 'mean normalization increases $<\mathrm{g}>$ ' of the students using the data from the pre- and post-tests. Odell (1997) did the calculations using the following formula:

$$
<g>=\frac{(\text { mean pretestscore })-(\text { mean posttestscore })}{100-(\text { mean } \text { pretestscore })}
$$

Boylan (2008) used Chi-square test in order to determine the existence of statistically significant difference in perceiving energy between male and female students and among various age levels. Hirça et al. (2008) and Köse et al. (2006) made their analyses over the percentages of correct and false answers.

Driver \& Warrington (1985) analyzed student answers using the most preferred classification method (framework). Finegold \& Trumper (1989), Trumper (1993; 1996; 1997a; 1997b) analyzed students' perceptions using the framework of 7 alternative conceptions (Energy is anthropocentric; ingredient; depository; transferable; product; functional; and obvious activity) identified by Watts (1983). Yet, researches evaluated the item of 'depository' under two subcategories as 'product' (depository) and 'cause' (active deposit). Trumper (1996; 1997a; 1997b; 1998) grouped students' answers to multiple choice questions as; the interval between $0-24 \%$ as "having scientifically incorrect perception", the interval between $25-75 \%$ as "sometimes having scientific perception", and the interval over $76 \%$ as "having scientific perception". Goldring \& Osborne (1994) made their analyses by coding 'correct answers as 3', 'partially correct answers as 2', and 'false answers as 1' and 'unrelated answers as 0'. Sağlam Arslan \& Kurnaz (2009) analyzed students' answers by coding 'short answers without explanation, meaningless answers and blank answers as 0 ',

\footnotetext{
${ }^{*} \mathrm{P}_{1}$ and $\mathrm{P}_{2}$ show rate of groups, $\mathrm{n}_{1}$ and $\mathrm{n}_{2}$ indicate the numbers in the group.
} 
'scientifically incorrect answers as 1', 'partially scientific answers as 2' and 'scientific answers as 3'. Sağlam Arslan (2009) classified student data she obtained from the first step of her 2-step method according to the five-step rubric shown below.

[0] No Understanding (NU): Blank, repeats question; irrelevant or unclear response,

[1] Alternative Conception (AC): Scientifically incorrect responses containing illogical or incorrect information,

[2] Partial Understanding with Specific Alternative Conception (PU/AC): Responses showing that the concept is understood but also containing alternative conception,

[3] Partial Understanding (PU): Responses containing some components of the scientifically accepted response,

[4] Sound Understanding (SU): Responses containing all components of the scientifically accepted response.

Sağlam Arslan (2009) analyzed the data she obtained from the second step of her study using the 5-step rubric listed below.

[0] No Drawing (ND): Blank.

[1] Incorrect graph (IG): None of the graph drawn correctly.

[2] Correct graph with incorrect graphs (CG/IGs): The graph directly related to the algebraic expression is correct, but the other two graphs are incorrect.

[3] Correct graphs with incorrect graph (CGs/IG): One of the graphs indirectly related to the algebraic expression is incorrect, but the other two graphs are correct.

[4] Correct graphs (CG): All three graphs are correct.

Papadouris et al. (2004) classified student answers about explaining the changes in physical systems as 'those who explain with energy', 'those who explain with a concept other than energy (force, electricity, etc.)'. Köse et al. (2006) analyzed the interview data using the codes of being "similar, different and independent". Ünal Çoban et al. (2007) made their analyses based on the codes derived from student answers and the categories derived from these codes. Yürümezoğlu et al. (2009) categorized students' answers in terms of similar statements and main themes. They also made comparisons to discover common theoretical constructs among the classifications they made. They were also found to make descriptions and interpretations.

Küçük et al. (2005), Duit (1984) and Watts (1983) did not mention the methods they used in their analyses.

\section{Findings}

The most important findings obtained by the researchers are presented in Table 5. For meaningful learning new knowledge should correspond to existing knowledge (Çalık, 2006; Özsevgeç, 2007) because students construct their new knowledge based upon their existing experiences, abilities and beliefs (Çepni, Akdeniz \& Keser, 2000; Çepni et al., 2001; Kurnaz $\&$ Çalık, 2008). When Table 5 is examined, it can be seen in many studies that students have difficulty in learning or have alternative concepts about defining energy. Trumper \& Gorsky (1993) determined in their study that, although there's no significant difference among the prior knowledge of students before the education process, at the end of the education process significant learning outcomes were found favoring those students who had higher cognitive levels. Trumper (1993) determined that there's no significant difference among the views of 6th -9 th graders about energy. Trumper $(1996 ; 1997 \mathrm{a} ; 1997 \mathrm{~b} ; 1998)$, Papadouris et al. (2004), Küçük et al. (2005), and Hırça et al. (2008) determined that some students perceived energy as a concrete entity that can be seen by the naked eye. Driver and Warrington (1985), 
and Duit (1984) determined in their study that students defined energy with daily life meaning rather than its scientific meaning and, Yuenyong et al. (2008) found that students took into account the environmental conditions, cultural beliefs and social values in constructing their knowledge about energy and had difficulty in understanding the relationship between political views and studies on energy. Köse et al. (2006), Kurnaz (2007), and Kurnaz \& Sağlam Arslan (2009) stated that students who defined energy scientifically concentrated only on the concept of energy as viewed in physics. Sağlam Arslan (2009) showed that although they were at different levels, students defined energy commonly as "the capability to act" and confirmed that students concentrated on the definition of energy concept from the perspective of physics.

Table 5. Important findings obtained from the related studies

\begin{tabular}{|c|c|}
\hline Important Findings & Studies \\
\hline Students think that energy is reproducible & Watts, 1983 \\
\hline $\begin{array}{l}\text { Students believe that energy cannot be stored in objects (coal, } \\
\text { petroleum, book etc.) }\end{array}$ & Watts, 1983 \\
\hline Students believe that motion/activity means energy. & Watts, 1983; Trumper, 1997a; 1998 \\
\hline Students think that only living things have energy. & $\begin{array}{l}\text { Watts, 1983; Ünal Çoban et al., } \\
\text { 2007; Hirça et al., } 2008\end{array}$ \\
\hline $\begin{array}{l}\text { Students think that inanimate things don't have energy because they } \\
\text { don't move. }\end{array}$ & $\begin{array}{l}\text { Watts, 1983; Ünal Çoban et al., } \\
\text { 2007; Hirça et al., } 2008\end{array}$ \\
\hline $\begin{array}{l}\text { Students confuse energy concept with concepts such as work, power or } \\
\text { force. }\end{array}$ & $\begin{array}{l}\text { Duit, 1984; Driver \& Warrington, } \\
\text { 1985; Trumper, 1993; 1996; 1997a; } \\
\text { 1997b; 1998; Küçük et al., 2005; } \\
\text { Papadouris et al., 2004; Kurnaz, } \\
\text { 2007; Kurnaz \& Sağlam Arslan, } \\
\text { 2009; Sağlam Arslan \& Kurnaz, } \\
\text { 2009; Sağlam Arslan, 2009 }\end{array}$ \\
\hline $\begin{array}{l}\text { Students define energy with its meaning in daily life rather than its } \\
\text { scientific meaning. }\end{array}$ & $\begin{array}{l}\text { Duit, 1984; Driver \& Warrington, } \\
1985\end{array}$ \\
\hline $\begin{array}{l}\text { Students usually have difficulty in adopting the idea of energy } \\
\text { degradation. }\end{array}$ & $\begin{array}{l}\text { Duit, 1984; Trumper, 1996; 1997a; } \\
\text { 1997b; } 1998\end{array}$ \\
\hline
\end{tabular}

Students frequently used classifications such as "product, cause and anthropocentric" prior to education process whereas after the education Finegold \& Trumper, 1989 process they used these classifications less frequently.

The classifications such as energy is "one of the ingredients of an
interaction; functional (source); fluid" are seldom used by students. interaction; functional (source); fluid" are seldom used by students.

The use of the classifications of energy such as it is "an obvious activity, the product of a process or situation" became more frequent Finegold \& Trumper, 1989 after education process.

Although the transformation of energy has a scientific value, they seldom used it before and after the study.

Finegold \& Trumper, 1989

There's no significant difference between the alternative conceptions of $6^{\text {th }}-9^{\text {th }}$ graders about energy.

Trumper, 1993

No significant relationship was found between the preconceptions of Trumper \& Gorsky, 1993 students.

At the end of the education process, more meaningful learning outcomes were obtained by the students whose cognitive levels were Trumper \& Gorsky, 1993 higher.

\begin{tabular}{ll}
\hline Students mostly view energy as "cause" and "anthropocentric". & Trumper, 1993; 1996 \\
\hline According to students, work is done in every energy transfer. & Goldring \& Osborne, 1994 \\
\hline Students are not able to explain what "conservation of energy" means. & $\begin{array}{l}\text { Goldring \& Osborne, 1994; Duit, } \\
\text { 1984; Trumper, 1997a; 1997b }\end{array}$ \\
\hline Students fail in determining the units of energy and power. & $\begin{array}{l}\text { Goldring \& Osborne, 1994; Sağlam } \\
\text { Arslan \& Kurnaz, 2009 }\end{array}$ \\
\hline Students think that energy is a concrete think that can be observed by & Trumper, 1996; 1997a; 1997b;
\end{tabular}

Students think that energy is a concrete think that can be observed by Trumper, 1996; 1997a; 1997b; 
the eye. (Energy is a kind of matter)

1998; Papadouris et al., 2004;

Küçük et al., 2005; Hırça et al., 2008

According to students, energy is what is needed to do something. Trumper, 1997a; 1998

The perceptions of biology and chemistry students are more successful than those of physics and science students.

Students think that plants and animals obtain their energy from water, Konuk \& Kılıç, 1999; Köse et al., air or soil. 2006

Students think that energy is not depository. Küçük et al., 2005

Students mostly concentrate on the energy concept from physics' point of view. Köse et al. 2006; Kurnaz, 2007;

Students think that potential energy can only be calculated based on the surface of the earth. Kurnaz \& Sağlam Arslan, 2009

Arslan, 2009

Although students can use complex formulas for the solution of Kurnaz, 2007; Kurnaz \& Sağlam problems, they can not justify their solutions. Arslan, 2009

Students think that objects moving at constant speed do work. Kurnaz, 2007 Ünal Çoban, et al., 2007; Kurnaz,

Students don't have sufficient knowledge about the forms of energy. 2007; Hirça et al., 2008; Boylan, 2008

Students think that potential energy is stored in protons, neutrons or electrons.

Hirça et al., 2008

Students think that our bodies' energy source is sleep.

According to students the energy source of our bodies is water.

According to students food is non-renewable source of energy.

According to some students natural gas and nuclear power are Boylan, 2008 renewable energy sources.

Students have scientifically incorrect perceptions about sound energy.

Students think that light energy will not "spark off" when wood is burned.

According to some students, a child and a man consume the same energy if they lift the same box to the same height.

Students believe that animals obtain energy from photosynthesis, fermentation or transpiration in order to survive.

Students state that some energy is lost during the process of energy transformation.

Environmental conditions, cultural beliefs and social values have an impact on students' construction of their knowledge about energy. Students have difficulty in understanding the relationship between political views and the studies on energy.

Students have difficulty in explaining the relationship between motion and energy.

Students can not explain the relationship between energy and matter.

Sağlam Arslan \& Kurnaz, 2009

Students' view of energy is not related to energy source, transfer or form.

Students can not distinguish energy source from different forms of energy.

Student can perceive the transformation of energy if there are observed / perceived differences (light, thermometer or propeller) during these transformations. Otherwise, they can't.

Students from different age levels pervasively define energy as the capability to do work.

Students have difficulty in representing their gains graphically.

Odell (1997) determined that the perceptions of students majoring in biology and chemistry were more successful than those of the students majoring in physics and science. Duit (1984), Driver \& Warrington (1985), Trumper (1993; 1996; 1997a; 1997b; 1998), Küçük 
et al. (2005), Papadouris et al. (2004), Kurnaz (2007), Kurnaz and Sağlam Arslan (2009), and Sağlam Arslan \& Kurnaz (2009) determined that students confused energy concept with the concepts such as work, power and force. Goldring \& Osborne (1994), and Sağlam Arslan \& Kurnaz (2009) showed that students failed in determining the units of energy and power concepts. Kurnaz (2007), and Kurnaz \& Sağlam Arslan (2009) suggest that although students could use complex formulas in solving energy related problems, they could not justify their solutions.

Finegold \& Trumper (1989) found that although the classifications about energy such as "product, cause and anthropocentric" were used by students prior to education process, these classifications were less adhered to after the education process. They also showed that the classifications about energy such as "being ingredient of an interaction, being functional (source), being fluid and the transformation property of energy" were seldom used and after the education process the classifications such as "being an obvious activity, a process or a product of a situation" were more adopted. Trumper $(1993 ; 1996 ; 1997 a ; 1998)$ showed in his studies that students defined energy as something needed to do something (cause) or anthropocentric. Similar findings about anthropocentric definitions were also reported by Boylan (2008) and Hirça et al. (2008). Boylan (2008) showed that students viewed sleep or water as the energy source of our bodies and that food was viewed as non-renewable energy source. Moreover, Hirça et al. (2008) found that students believed that if a child and a man moved the same box to the same height, then they would spend the same energy. Related to this point on energy transfer, Duit (1984), Goldring \& Osborne (1994), Trumper (1996; 1997a; 1997b; 1998) and Kurnaz (2007) reached to similar findings. Goldring \& Osborne (1994) found that students believed that work must be done in every energy transfer, Duit (1984) and Trumper $(1996 ; 1997 a ; 1997 b ; 1998)$ showed that students had difficulty in adopting the idea of energy degradation, Kurnaz (2007) showed that students thought that work was done with constant speed, and Hirça et al. (2008) found that students believed that some of the energy is lost during energy transfer. It's obvious that energy can not be created or destroyed. Students' expressions that energy may be destroyed make us think that the conservation of energy is not properly grasped by the students. This was also suggested by the results of the works by Goldring \& Osborne (1994), Duit (1984), and Trumper (1997a; 1997b). Related to other living things, Köse et al. (2006) and Konuk \& Kilıç (1999) reported that students believed plants and animals obtain their energy from water, air and soil; and Hurça et al. (2008) found that students believed animals obtained the necessary energy to survive from photosynthesis, fermentation or transpiration.

Yürümezoğlu et al. (2009) found that students could not distinguish energy source from different forms of energy. Researchers also showed that students could perceive energy transfer if there're observed / perceived properties during energy transfer and otherwise they could not. Kurnaz (2007), Ünal Çoban et al. (2007), Hırça et al. (2008), Boylan (2008), and Kurnaz \& Sağlam Arslan (2009) found that students had scant knowledge about the forms of energy, though they mostly knew the forms of kinetic and potential energy. Ünal Çoban et al. (2007) and Kurnaz (2007) claimed that this finding stemmed from the fact that energy concept is taught based upon mechanics. Although the forms of kinetic and potential energy are known by the students, their knowledge is found to be insufficient to explain them (Kurnaz, 2007; Kurnaz \& Sağlam Arslan, 2009). Hırça et al. (2008) determined that students believed that potential energy is stored in protons, neutrons or electrons. Kurnaz (2007), and Kurnaz \& Sağlam Arslan (2009) determined that students believed that potential energy is a measurement dependent on the surface of earth. Boylan (2008) found that students defined natural gas and nuclear energy as renewable energy sources and they had scientifically incorrect perceptions about sound energy. 
According to Yürümezoğlu et al. (2009), the energy concept in students' minds is different from the scientific views about form, source and transferability of energy. Watts (1983), Ünal Çoban et al. (2007) and Hirça et al. (2008) found that students believed that only living things had energy and inanimate things had no energy because they did not move. Watts (1983) and Küçük et al. (2005) also found that students viewed energy as nondepository and as being identical to motion. Trumper $(1997 \mathrm{a} ; 1998)$ showed that students believed that if there was motion then there would be energy, Sağlam Arslan \& Kurnaz (2009) found that students had difficulty in explaining the relationship between motion/activity and energy. Boylan (2008) found that students believed no light energy would emerge when wood is burned, whereas Watts (1983) showed that students perceived energy as reproducible (can be created). Sağlam Arslan \& Kurnaz (2009) found that students were not able to explain the relationship between energy and matter.

\section{Results}

The most important results obtained by the researchers were given in Table 6. As shown in Table 6, Watts (1983) suggested that students have alternative conceptions about energy and he classified these concepts under 7 titles: 'Energy is anthropocentric, energy is depository, energy is an ingredient of energy formation, energy is an obvious activity, energy is a product, energy is fluid, energy is functional'. Trumper (1993) claimed that students should be introduced with the forms, transformation and conservation of energy at 5 th grade and teaching process should be structured by taking into account students' alternative conceptions such as "energy is anthropocentric, energy is the product or cause of a process". Trumper $(1996 ; 1997 \mathrm{a} ; 1997 \mathrm{~b})$ concluded that students had distinct, scientifically incorrect perceptions. Boylan (2008) concluded that students had alternative concepts about renewable and non-renewable energy sources, and Yuenyong et al. (2008) concluded that students have difficulty in relating public affairs and the studies on energy. Driver and Warrington (1985) concluded that students seldom preferred the conservation of energy in interpreting physical situations, Sağlam Arslan \& Kurnaz (2009) concluded that students could not relate daily life situations with energy and related concepts, Goldring \& Osborne (1994) concluded that there's no significant relationship between the qualitative and quantitative answers of students. Kurnaz (2007), and Kurnaz \& Sağlam Arslan (2009) concluded that students had insufficient knowledge about the relationship between energy and work, the forms of energy; students had low proficiency in handling problems which require explanation and interpretation; and students became automated in using formulas in solving problems. The negative correlation between students' using formulas and conceptual explanation abilities was also reported in students' shifting between different representations (Sağlam Arslan, 2009).

Trumper \& Gorsky (1993) emphasized that structuring the instruction of energy concept by building upon students' pre knowledge would facilitate learning. Duit (1984) and Trumper (1998) concluded that physics education is not sufficiently effective in teaching energy concept, and Küçük et al. (2005), Ünal Çoban et al., (2007), Hirça et al., (2008) and Yürümezoğlu (2009) reported that students developed scientifically incorrect mindsets as a result of elementary education process. Konuk \& Kilıç (1999), and Köse et al. (2006) concluded that students begin university with misconceptions, and these misconceptions persist throughout education processes. Odell (1997) concluded in his/her study on students from different programs that there are differences among the perceptions of students about energy before and after attending basic courses. On the other hand, Sağlam Arslan (2009) concluded that there are similarities among learning of students at different age levels. She also concluded that students could not define energy autonomously because institutional 
teaching had deep impact on students. According to Finegold \& Trumper (1989), students' prior views persist after instruction and this shows teachers have a low level of achievement in teaching energy concept.

Table 6. Important results obtained from the related studies

\begin{tabular}{l} 
Results \\
\hline Students have different alternative conceptions about energy \\
\hline Physics education is not sufficiently effective in teaching energy concept. \\
In interpreting physical situations, the conservation of energy is rarely \\
preferred by students. \\
The persistence of students' prior conceptions after instruction shows that \\
teachers' achievement level is low. \\
Students should start to meet with the forms, transfer and conservation of \\
energy at $5^{\text {th }}$ grade. \\
\hline Education process should be structured by taking into account students' \\
alternative conceptions such as “energy is anthropocentric, energy is the \\
product or cause of a process". \\
Structuring instructional design upon prior knowledge of students \\
facilitates learning. \\
No significant relationship was found among the qualitative and \\
quantitative answers of students.
\end{tabular}

Students have distinct and scientifically incorrect perceptions.

Studies

Watts, 1983

Duit, 1984; Trumper, 1998

Driver \& Warrington, 1985

Finegold \& Trumper, 1989

Trumper, 1993

Trumper, 1993

Trumper \& Gorsky, 1993

Goldring \& Osborne, 1994

There are differences among the perceptions of physics, chemistry, biology and science students regarding energy before and after basic courses.

Students bring misconceptions to university education and these misconceptions persist after this process.

After elementary education process, students develop scientifically incorrect mindsets about energy concept.

Trumper, 1996; 1997a; 1997b

Odell, 1997

Konuk \& Kılıç, 1999; Köse et al., 2006

Küçük et al., 2005; Ünal Çoban et al.,2007; Hirça et al., 2008;

Yürümezoğlu et al., 2009

Students have difficulty in relating studies on energy and public affairs. Yuenyong et al.,2008

Students have alternative concepts about renewable and non-renewable energy sources.

Students don't have sufficient knowledge about the relationship between Kurnaz, 2007; Kurnaz \& Sağlam work and energy and the forms of energy.

Arslan, 2009

Individual abilities of students to implement practices requiring Kurnaz, 2007; Kurnaz \& Sağlam explanation and interpretation are very limited.

Arslan, 2009

Students couldn't justify the formulas they've used in solving problems Kurnaz, 2007; Kurnaz \& Sağlam and this showed that they automatically use formulas.

Students can not explain daily life situations with energy and related concepts.

Arslan, 2009

The agreement among the definitions of students about energy shows that there are also similarities between their learnings.

Sağlam Arslan \& Kurnaz, 2009

Sağlam Arslan, 2009

Students have difficulty in shifting among different representations.

Sağlam Arslan, 2009

Institutional instruction has deep impact on students' lack of defining energy autonomously.

Sağlam Arslan, 2009 


\section{Implications of the Studies}

The recommendations made by the researchers are presented in Table 7 .

Table 7. Important data given in the related studies

\begin{tabular}{|c|c|}
\hline Recommendations & Studies \\
\hline $\begin{array}{l}\text { Students' prior knowledge should be valued and can be restructured. } \\
\text { Therefore, conceptual change approach should be emphasized. }\end{array}$ & Watts, 1983 \\
\hline $\begin{array}{l}\text { Instruction based on degradation of energy will help better perception } \\
\text { of the conservation of energy. }\end{array}$ & Duit, 1984 \\
\hline $\begin{array}{l}\text { Students should not only be urged to do exercises related to physical } \\
\text { situations. Instead, they should be presented with challenging } \\
\text { alternative problems. }\end{array}$ & $\begin{array}{l}\text { Driver \& Warrington, } \\
1985\end{array}$ \\
\hline $\begin{array}{l}\text { Discovery learning method with small groups is thought to be effective } \\
\text { in teaching energy concept and thus it's recommended. }\end{array}$ & $\begin{array}{l}\text { Finegold \& Trumper, } \\
1989\end{array}$ \\
\hline $\begin{array}{l}\text { In order to restructure students' perceptions scientifically, students } \\
\text { should be introduced with energy concept at } 5^{\text {th }} \text { grade and they should } \\
\text { be informed about as many forms of energy as possible. }\end{array}$ & Trumper, 1993 \\
\hline $\begin{array}{l}\text { It's recommended to conduct different studies on how student learning } \\
\text { happens. }\end{array}$ & $\begin{array}{l}\text { Trumper \& Gorsky, } \\
1993\end{array}$ \\
\hline $\begin{array}{l}\text { Concept maps and discussion groups may be used in teaching energy } \\
\text { concept. }\end{array}$ & $\begin{array}{l}\text { Goldring \& Osborne, } \\
1994\end{array}$ \\
\hline $\begin{array}{l}\text { Constructivist approach which takes into account students' existing } \\
\text { knowledge is recommended. }\end{array}$ & $\begin{array}{l}\text { Trumper, 1996; 1997a; } \\
\text { 1997b }\end{array}$ \\
\hline Alternative teaching methods should be developed. & $\begin{array}{l}\text { Trumper, 1998; Ünal } \\
\text { Çoban et al., } 2007\end{array}$ \\
\hline $\begin{array}{l}\text { Alternative concepts of students before instruction about energy and } \\
\text { related concepts should be identified. }\end{array}$ & Küçük et al., 2005 \\
\hline $\begin{array}{l}\text { Energy and related concepts should be presented coherently by stressing } \\
\text { the differences. }\end{array}$ & $\begin{array}{l}\text { Küçük et al., 2005; } \\
\text { Hirça et al., 2008; } \\
\text { Sağlam Arslan \& } \\
\text { Kurnaz, } 2009\end{array}$ \\
\hline $\begin{array}{l}\text { Alternative teaching methods using problem based teaching, modeling, } \\
\text { computer simulations, concept maps, and conceptual change texts } \\
\text { should be developed. }\end{array}$ & $\begin{array}{l}\text { Köse et al., 2006; Hırça } \\
\text { et al., } 2008\end{array}$ \\
\hline Science curricula are recommended to have a cross-cultural view. & Yuenyong et al., 2008 \\
\hline $\begin{array}{l}\text { Subjects such as energy sources and climate change should be presented } \\
\text { by connecting to real life. }\end{array}$ & Boylan, 2008 \\
\hline $\begin{array}{l}\text { A balanced and sequential view is recommended in the qualitative and } \\
\text { quantitative operations in teaching energy concept. }\end{array}$ & Kurnaz, 2007 \\
\hline $\begin{array}{l}\text { The teaching of energy concept should not be constrained to calculation } \\
\text { activities but also include various types of activities. }\end{array}$ & $\begin{array}{l}\text { Kurnaz, 2007; Kurnaz \& } \\
\text { Sağlam Arslan, } 2009\end{array}$ \\
\hline $\begin{array}{l}\text { Energy should be defined in a broader sense rather than defining it } \\
\text { based on work concept. }\end{array}$ & $\begin{array}{l}\text { Kurnaz, 2007; Kurnaz \& } \\
\text { Sağlam Arslan, } 2009\end{array}$ \\
\hline $\begin{array}{l}\text { Different materials such as concept maps and conceptual change texts } \\
\text { should be used in teaching process. }\end{array}$ & $\begin{array}{l}\text { Sağlam Arslan \& } \\
\text { Kurnaz, } 2009\end{array}$ \\
\hline $\begin{array}{l}\text { Teaching process should involve different experiments and activities } \\
\text { ranging from daily life examples to a large number of examples. }\end{array}$ & $\begin{array}{l}\text { Yürümezoğlu et al., } \\
2009\end{array}$ \\
\hline $\begin{array}{l}\text { Graphics which are proved to be important in teaching energy concept } \\
\text { should be used. }\end{array}$ & Sağlam Arslan, 2009 \\
\hline
\end{tabular}


Watts (1983) suggests that students' prior knowledge is valuable and recommends that students may undergo a conceptual change by designing instruction process based upon this prior knowledge. For this aim, Watts suggests that teachers should have knowledge about students' alternative conceptions. Trumper (1993) recommends that students should be introduced with energy concept at 5 th grade and they should be informed about different forms of energy in order to structure their perceptions scientifically.

The underlying reason why students can not understand the substance of energy concept is that a clear cut definition is not presented to them (Driver \& Warrington, 1985; Domenech et al., 2007). For this point, Kurnaz (2007), and Kurnaz \& Sağlam Arslan (2009) recommends that energy concept should be defined not only based on work concept but in a broader sense that will reflect an interdisciplinary base. Duit (1984) suggests that taking into account energy degradation in the instructional design would help students understand the conservation of energy. According to Duit, daily experiences may deceptively show that energy is lost and this contradicts the conservation of energy. Therefore, energy degradation will help bridge the gap between daily meaning and scientific meaning. Yuenyong et al. (2008) claim that their curriculum should have a cross-cultural view. Boylan (2008) recommends that subjects such as energy sources and climate change should be taught by connecting to real life.

Finegold \& Trumper (1989) suggest that discovery learning in small groups may be effective in teaching energy concept, Goldring \& Osborne (1994) suggest that concept maps and discussion groups should be used in teaching energy concept, and Trumper \& Gorsky (1993), Trumper (1998) and Ünal Çoban et al. (2007) recommend that alternative teaching methods should be developed to facilitate learning energy concept. Driver \& Warrington (1985), Kurnaz (2007) and Kurnaz \& Sağlam Arslan (2009) suggest that it should be avoided to concentrate only on mathematical exercises in physical situations, and instead alternative activities should be used to provoke reflection. In this regard, Kurnaz (2007) suggest that a balanced and sequential view should be adopted in quantitative and qualitative operations in teaching energy concept. Küçük et al. (2005) recommend that, students' alternative concepts about energy and related concepts should be determined prior to instruction. At this point, Trumper (1996; 1997a; 1997b) recommends using constructivist approach which takes students' existing knowledge into account. Köse et al. (2006) and Hirça et al. (2008) suggest that alternative teaching methods should be developed by using problem based teaching, modeling, simulations, concept maps and conceptual change texts. Similarly, Sağlam Arslan \& Kurnaz (2009) recommend making use of materials in teaching process such as concept maps and conceptual change texts. Sağlam Arslan (2009) emphasizes that graphics which are proven to be effective in teaching energy concept should be used. Küçük et al. (2005), Hirça et al. (2008), and Sağlam Arslan \& Kurnaz (2009) recommend that comparative approaches should be used in teaching energy and related concepts. Yürümezoğlu et al. (2009) recommend that several examples from daily life, different experiments and activities should be used in teaching process.

\section{Future Research}

First of all we may say that there are still new ways of examining students' understandings. For example, a classroom-based research has not been carried out or mental models of students have not been examined. However, it is obvious that determining students' understanding about energy concept or any other concept is not enough. These are, basically, as science educators, important cases which we have to overcome. Therefore, further research must be concentrated on how to tackle these obstacles. On the other hand, we know that there are too many research papers including alternative teaching methods about energy concept and claiming that their methods made a significant contribution to student's learning 
experience/motivation/skills (Kurnaz \& Çalık, 2009). Therefore, it should also research that if we have alternative sufficient methods to teach energy effectively why still it is difficult to teach energy or why still students are hard to learn it. Can be a dilemma between the results of teaching energy with alternative methods studies and examining students' understandings studies? Are we neglecting the results of teaching energy with alternative methods studies? Are we hard to reach teachers to introduce our methods or vice versa? If so why and how can we remove obstacles?

\section{References}

Bodner, G.M. (1990). Why Good Teaching Fails and Hard-Working Students Do Not Always Succeed. Spectrum, 28(1), 27-32.

Boylan, C. (2008). Exploring elementary students' understanding of energy and climate change. International Electronic Journal of Elementary Education, 1(1), 1-15.

Carey, S. (1986). Cognitive science and science education. American Psychologist, 41(10), $1123-1130$.

Cohen, L., Manion, L. \& Morrison, K. (2007). Research Methods in Education, 6th ed. New York: Routledge.

Çalık, M., Ayas, A. \& Ebenezer, J.V. (2005). A review of solution chemistry studies: insights into students' conceptions. Journal of Science Education and Technology, 14, 29-50.

Çalık, M. (2006). Devising and Implementing Guide Materials Related to "Solution Chemistry" Topic in Grade 9 Based on Constructivist Learning Theory. Unpublished Doctoral Thesis, Karadeniz Technical University, Trabzon, Turkey.

Domenech, J.L., Gil-perez, D., Gras-marti, A., Guisasola, J., Torregrosa, J.M., Salinas, J., Trumper, R., Valdes, P. \& Vilches, A. (2007). Teaching of Energy İssues: A Debate Proposal for a Global Reorientation. Science \& Education, 16, 43-64.

Driver, R. \& Warrington, L. (1985). Students use of the principle of energy conservation in problem situations. Physics Education, 29, 171-176.

Duit, R. (1984). Learning the Energy Concept in School-Empirical Results from the Philippines and West Germany. Physics Education, 19, 59-66.

Dysthe, O. (2002). Theoretical background for portfolios as learning and assessment tools in teacher education (Paper presented at the NERA/NFPF Conference, Tallin).

Finegold, M. \& Trumper, R. (1989). Categorizing pupils' explanatory frameworks in energy as a means to development of a teaching approach. Research in Science Education, 19, 97-110.

Goldring, H. \& Osborne, J. (1994). Students' Difficulties with Energy and Related Concepts. Physics Education, 29(1), 26-32.

Guba, E.G. \& Lincoln, Y.S. (1989). Fourth generation evaluation. Newbury Park, California: Sage.

Harrison, A.G. \& Treagust, D.F. (2000). Learning about atoms, molecules, and chemical bonds: A case study of multiple-model use in grade 11 chemistry. Science Education, $84,352-381$.

Hırça, N., Çalık, M. \& Akdeniz, F. (2008). Investigating grade 8 students' conceptions of 'energy' and related concepts. Journal of Turkish Science Education, 5(1), 75-87. 
Konuk, M. \& K1lıç, S. (1999). Misconceptions of freshman students about energy sources in plants and animals. III. National Science Education Symposium'98, Proceedings book, 199-202.

Köse, S., Bağ, H., Sürücü, A. \& Uçak, E. (2006). The Opinions of Prospective Science Teachers' About Energy Sources for Living Organisms. International Journal of Enviromental and Science Education, 1(2), 141-152.

Kurnaz, M.A. (2007). Analysis of Learning Situations of the Energy Concept at University Year 1 Level. Unpublished Master Thesis, Karadeniz Technical University, Trabzon, Turkey.

Kurnaz, M.A. \& Çalık, M. (2008). Using Different Conceptual Change Methods Embedded within 5E Model: A Sample Teaching for Heat and Temperature, Journal of Physics Teacher Education. Online, 5(1), 3-10.

Kurnaz, M.A. \& Çalık, M. (2009). A thematic review of 'energy' teaching studies: focuses, needs, methods, general knowledge claims and implications. Energy Education Science and Technology Part B: Social and Educational Studies, 1(1), 1-26.

Kurnaz, M.A. \& Sağlam Arslan, A. (2009). Using the Anthropological Theory of Didactics in Physics: Characterization of the Teaching Conditions of Energy Concept and the Personal Relations of freshmen to this Concept. Journal of Turkish Science Education, 6(1), 72-88.

Küçük, M., Çepni, S. \& Gökdere, M. (2005). Turkish Primary School Students' Alternative Conceptions about Work, Power and Energy. Journal of Physics Teacher Education Online, 3(2), 22-28.

Mathews, M.R. (2000). Constructivism in Science and Mathematics Education. In D.C. Phillips (Eds.), National Society for the Study of Education, $99^{\text {th }}$ Yearbook, Chicago, University of Chicago Press, 161-192.

Nakhleh, M.B. (1992). Why some students don't learn chemistry? Journal of Chemical Education, 69(3), 191-196.

Odell, J.L. (2005). Student Understanding of Conservation of Energy and Mass in Introductory University Science Courses. Unpublished Master Thesis, The University of Maine, Orono.

Osborne, R.J. \& Gilbert, J.K. (1980). A method for investigating concept understanding in science. European Journal of Science Education, 2, 311-321.

Osborne, R.J. \& Wittrock, M.C. (1983). Learning science: a generative process. Science Education, 67(4), 489-508.

Osborne, R. \& Freyberg, P. (1985). Children's Science. In R. Osborne and P. Freyberg (Eds.), Learning in Science: The implications of children's science, 5-14, Hong Kong: Heinemann.

Özsevgeç, T. (2007). Determining Effectiveness of Guided Materials about "Force and Motion” Unit Based On the 5E Model for Elementary Students. Unpublished Doctoral Thesis, Karadeniz Technical University, Trabzon, Turkey.

Papadouris, N., Kyratsi, T. \& Constantinou, C.P. (2004). Student Understanding of Energy as a Model that Accounts for Changes in Physical Systems (Paper presented at the GIREP Conference Proceedings: Teaching and Learning Physics in new Contexts, Ostrava). 
Sağlam Arslan, A. \& Kurnaz, M.A. (2009). Prospective physics teachers' level of understanding energy, power and force concepts. Asia-Pacific Forum on Science Learning and Teaching, 10(1), Article 6.

Sağlam Arslan, A. (2009). Cross-Grade Comparison of Students' Understanding of Energy Concepts. Journal of Science Education and Technology, 19(3), 303-313.

Taber, K.S. (2002). Alternative conceptions in chemistry: Prevention, diagnosis and cure? The Royal Society of Chemistry, London.

Trumper, R. (1993). Children's energy concepts: a cross-age study. International Journal of Science Education, 15(2), 139-148.

Trumper, R. \& Gorsky, P. (1993). Learning about energy: the influence of alternative frameworks, cognitive levels, and closed-mindedness. Journal of Research in Science Teaching, 30, 637-648.

Trumper, R. (1996). A survey of Israeli physics students' conceptions of energy in pre-service training for high school teachers. Research in science \& Technological Education, 4(2), 179-192.

Trumper, R. (1997a). A survey of conceptions of energy Israeli pre-service high school biology teachers. International Journal of Science Education, 19(1), 31-46.

Trumper, R. (1997b). The need for a change in elementary school teacher training: the case energy concept as an example. Educational Research, 39(2), 157-174.

Trumper, R. (1998). A longitudinal study of physics' students' conceptions on energy in preservice training for high school teachers. Journal of Science Education and Technology, 7(4), 311-318.

Watts, D.M. (1983). Some Alternative Views on Energy, Physics Education, 18, 213-217.

Yager, R. (1991). The Constructivist Learning Model Towards Real Form in Science Education, The Science Teacher, 58(6), 52-57.

Yuengyong, C., Jones, A. \& Yutakom, N. (2008). A comparison of Thailand and New Zealand students' ideas about energy related to technological and societal issues. International Journal of Science and Mathematics Education, 6, 293-311.

Ünal, S., Calik, M., Ayas, A. \& Coll, R.K. (2006). A review of chemical bounding studies: needs, aims, methods of exploring students' conceptions, general knowledge claims and students' alternative conceptions. Research in Science \& Technological Education, 4, 141-172.

Ünal Çoban G., Aktamış H. \& Ergin Ö. (2007). The Views of $8^{\text {th }}$ Grade Students about Energy. G. U. Kastamonu Ĕ̈itim Dergisi, 15 (1), 175-184.

Yürümezoğlu, K., Ayaz, S. \& Çökelez, A. (2009). Grade 7-9 Students' Perceptions of Energy and Related Concepts. Necatibey Ĕgitim Fakültesi Elektronik Fen ve Matematik Ĕ̈itimi Dergisi (NEFMED), 3(2), 52-73.

White, R.T. \& Gunstone, R.F. (1992). Probing Understanding, The Falmer Press, London. 